\title{
The Role of Risk Management on Financial Performance of Banking Institutions in Rwanda
}

Harelimana JB*

Institute of Higher Education of Ruhengeri, Musanze, Rwanda, Musanze, Rwanda

\begin{abstract}
The aim of this study is to assess the role of risk management on financial performance in Rwanda institutions: Case study of Unguka bank Ltd undertaken within period 2012-2016. The data were collected through a questionnaire designed for 30 staff's members of Unguka bank Ltd where both quantitative and qualitative techniques were employed. The interviews were conducted with key informants from like the Unguka bank Ltd staffs. Findings shows that the determinants of risk management in Unguka bank Ltd are credit risk, operational risk, and interest rate and liquidity risk are the determinants of risk management. The results shows that Unguka bank Ltd is profitable during the covered period because the standard ratio of return on asset is $1 \%$ may factors are the cause of that profitability but the quality service are the main cause of the increase of its profitability. The researcher also found out that there is a very strong relationship between risk management and financial performance. The role of risk management in Unguka bank Ltd is to improve profitability which accounted for $43.3 \%$ of the responses. It was found that the four independent variables moderately predict the performance of Unguka bank Ltd that means the model explains $69.5 \%$ the variance on the performance of Unguka bank Ltd. The results confirm the hypothesis because the linear regression $F$-test results $(F=8.741$; and $5 \mathrm{df})$ are significant at $p<0.05$. The study conducted a multiple regression analysis so as to determine the regression coefficients $(\beta)$ which shows that $\beta 0=10138$ and which means that all the independent variables have a significant contribution to Unguka bank Ltd-Nyarugenge branch. After analysis, it is recommended that Unguka bank Ltd should emphasize more on training its personnel continuously particularly those in risk management in order to enable them apply accepted tools of risk management in a professional manner and to enable them give relevant and reliable answers to questions credit risk management.
\end{abstract}

Keywords: Risk management; Financial performance

\section{Introduction and Background}

In Rwanda, the path of financial activity, which concerns banking, insurance, savings and loans associations, etc. had always been paved with numerous contingencies after the genocide of 1994 that destroyed the big part of the national wealth. Contingencies are referred to here as risks that symbolize a situation that cannot be controlled or perfectly foreseen Diacon and Carter [1]. These risks cannot be predicted accurately and this therefore gives rise to the involvement of a careful management. The Rwandan financial framework, as any other financial system in the world, deals highly with risks in its every day management. As a reason for this, we can mention the fact that there are factors that are not under the control of managers such as globalization, world changes or market variables like price changes or stock exchange trends.

Historically the banking and finance management in Rwanda has always been subject to some major risks, the careful management of which has always led to survival in the financial sector. Many Rwandan financial houses handle these risks on a daily basis in order to grow and encounter rapid changes. Therefore, risks must be understood and carefully managed for a proper decision making in the Rwanda financial system.

Risk management is of a big importance in the management decision making in financial institutions because risk management must meet certain objectives to keep your business running efficiently [2].

Rwanda is growing up with a vision of being a business country, knowing that the bank is very useful to the majority of Rwanda and this is a gate of economic growth of Rwandan citizens (private bank assessed on $25^{\text {th }}$ July 2014). In the past few years the banking institutions were experiencing a problem of ineffectiveness and inefficiency of loans portfolios. This has led to poor performance of the banking sector as very high proportion of fund as locked up into no performing assets which deprives the economy of continuous flow of funds that would be used to finance investment projects.

The analysis of risk management is very important within the department of the management of the risk within any bank to maintain an increasing profitability of risk management lot of credits that are granted by the Rwandan banks are not repaid efficiently, what constitutes a danger to their profitability.

In 2006, some of banks were found to be in a bad standing and some of them were stopped. This information highlights the problem of liquidity risks encountered by much banks in Rwanda. The explanation of this fact is in the recovery of the big amount of credits they encounter and the failure of their recovery. This is the case exists in Rwanda. For example of Microfinance such as Igisubizo, Ongera, Urumuri, etc.

An analysis of this case implies that the standing of Unguka bank Ltd that is still serving its client was based on the minimization of credit risks and has increased the amount in savings accounts. For the year 2007, the members of the micro finances Unguka have saved 68873461 frws, either $16.9 \%$. In 2008, the totals of savings were 136.629 .946 Frws, that is $33.16 \%$ and in 2009 the members of the bank Ltd saved 199.690.233 Frws 49.3\% (consulted on May 2014).

${ }^{*}$ Corresponding author: Harelimana JB, Institute of Higher Education of Ruhengeri, Musanze, Rwanda, Musanze, Rwanda, Tel: 250(0)788903032; E-mail: harelijordan@yahoo.fr

Received January 09, 2017; Accepted January 24, 2017; Published January 28 2017

Citation: Harelimana JB (2017) The Role of Risk Management on Financial Performance of Banking Institutions in Rwanda. Bus Eco J 8: 284. doi: 10.4172/2151-6219.1000284

Copyright: ( 2017 Harelimana JB. This is an open-access article distributed under the terms of the Creative Commons Attribution License, which permits unrestricted use, distribution, and reproduction in any medium, provided the original author and source are credited. 
According to Sundharam and Varshney [3], said that the most profitable activity of finance institutions is lending and every institution strives to optimize its net profit by employing its surplus cash into different activities. However, non-performing loans impair the finance institution profitability rendering it unable to meet obligations of customers and they may end up losing their reputations in the market.

It is well known that perform well are those with less or no loan problems. And it is also known that loan portfolio is the major source of profit, also it is the major source of risk. The risk is born at the time of a loan debtor failing to meet his/her contractual obligations. The unpaid loans are the assets of bank that have not been recovered which result into losses, and losses can drive the Unguka bank Ltd to bankruptcy and subsequent closure.

On the other hand, efforts to recover these assets involve a lot of legal costs which aggregates the situation. Even some measures including improvement of risk management techniques analysis and evaluation have been carried out to reduce or completely prevent non-performance loans, but the problem still persists. In fact, risk management helps Unguka bank Ltd to performing well.

A hypothesis is a research's anticipated explanation or opinion; consist of either a suggested explanation or for an observable phenomenon or a reasoned proposal predicting causal correlation among a multiple phenomenon.

The study will focus on the following objectives:

1. Credit risk, interest rate risk, liquidity risk, operational risksare the determinants of risk management in Unguka bank Ltd.

2. Return on asset, Return on equity, Net profit margin and Sustainable growth rate are the indicators of financial performance of Unguka bank Ltd.

3. The determinants of risk management explain positively the financial performance indicators in Unguka bank Ltd.

\section{Objectives}

The general objective of this study is to assess the role of risk management on financial performance in banking institutions in Rwanda, Specifically:

1. To assess the determinants of risk management in Unguka bank Ltd.

2. To analyze the indicators of financial performance of Unguka bank Ltd.

3. To measure the relationship between determinants of risk management and indicators of financial performance in Unguka bank Ltd.

\section{Literature Review}

According to Gallati [2], risk is defined as a condition in which there exists an exposure to adversity, or a condition in which there exists a possibility of deviation from a desired outcome that is expected or hoped for. Risk management is a process that identifies loss exposure faced by an organization and selects the most appropriate techniques for treating such exposures. Because the term" risk "is ambiguous and has different meanings, many risk managers use the term "loss exposure" to identify potential losses [2].

Performance can be defined as an approach determining the extent to which set objectives of an organization are achieved in a particular period of time. The objectives or goals can be in financial or nonfinancial terms. Performance may be determined by macro and microfactors. According to Williamson, macro-economic factors are those pertinent to a broad economy at the regional or national level and affect a large population rather than a few select individuals. Macro factors include GDP growth, inflation, unemployment, interest rates, exchange rate and level of competition. Micro factors include individual risk exposure, operating strategies and degree of management strategies. Any of many different mathematical measures to evaluate how well a company is using its resources to make a profit. Common examples of financial performance include operating income, earnings before interest and taxes, and net asset value. It is important to note that no one measure of financial performance should be taken on its own. Rather, a thorough assessment of a company's performance should take into account many different measures. Evaluating the financial performance of a business allows decision-makers to judge the results of business strategies and activities in objective monetary terms. A company financial performance is directly influenced by its market position.

Profitability can be split into its main components; net turnover and net profit margin. Ross et al. [4], argue that both components influence profitability. High turnover means better use of assets owned by the company and therefore better efficiency while a higher profit margin means that the entity has a substantial market power.

Risk and growth influences a firm's financial performance. Since market value is conditioned by company's results, the level of risk exposure can cause changes in its market value. High risk business should have high returns. Economic growth helps a firm to achieve a better position on the financial markets, because market value also takes into consideration expected future profits.

Several studies have been carryout on the role of risk management on financial performance. In his study, John, entitled the "role of risk management on financial performance in banking institutions" with the objectives of assessing the determinants of risk management and analyzing the indicators of financial performance of banking sector. $\mathrm{He}$ found that risk management has a significant effect on organizational effectiveness among the construction of bank institutions. The study found that good management of risk management enhances performance of banking institutions. The study also found that risk management leads to good financial reports and also leading to better decision- making of the investors.

The study entitled "The contribution of risk management to the growth of financial report in Microfinance' was carried out by Dahir [5]. The main objective of the study was to analyze credit risk management practices employed by banking, cause of operation ling of borrowers and propose the corrective measures in order to reduce the level of credit risk, exposed that because of the many clients that are borrowers with computerized accounting system more importantly its ability to produce and present relevant and faithful representative financial reports to end users. The government of Rwanda is assisting microfinance to transfer into a common computerized accounting system. This is going to serve as a platform in which all the rural microfinance in the country are going to be networked to each other to facilitate faster and efficient banking. He concluded that risk management is necessary to identifying, analyzing, assessing, treating, monitoring and communicating of organization. Risk management therefore plays six main functions in an organization.

Narwal and Jindal [6] examined the impact of corporate governance 
on the profitability of Indian textile sectors. They collected data from annual reports of textiles companies for the period of five year ranging from 2009 to 2014 . They found a strong positive association between director's remuneration and profitability. The Audit Committee members is observed negative associated with the profitability.

Ojulari explores the relationships that exist between corporate governance and the profitability of financial institutions. He selected 25 companies listed in the Nigerian stock exchange. The results show that the two variables (i.e., corporate governance and financial profitability) are more positively related on an individual proxy basis than on an overall proxy basis. The overall impact of corporate governance on the profitability is also negative so also are the result of the regression models. The results show that although there is a relationship between the two variables, the predictive power of corporate governance on companies' profitability is too low to be meaningful.

\section{Methodology}

In this section tools and techniques were used to achieve the study objectives discussed above. Both primary and secondary data were used in collection of data and then analysed through SPSS.

\section{Data collection}

Data were collected through documentary sources, observation, questionnaires and structure and unstructured interviews where both quantitative and qualitative data were used. The data were collected from the population size that covered all population of Unguka bank Ltd. The sample size is equal to the populations of Unguka bank whose are 30 staffs. After the data collected were organized, edited and coded, quantitative data were entered into Statistical Package for Social Science (SPSS) and were analyzed using descriptive statistics.

\section{Models and techniques}

To measure the relationship between the variables, multiple regression models were used to determine this relationship. In doing so, the regression model below was used:

$$
y=\beta 0+\beta 1 \times 1+\beta 2 \times 2+\beta 3 \times 3+\beta 4 \times 4+\varepsilon .
$$

Where $y=$ dependent variable (Financial Performance of financial institution) such as sustainable growth rate, return on asset, return on equity, net income; $\beta 0-\beta 4=$ model parameters or coefficients; $x_{1}-x_{4}=$ independent variables (risk management) like credit risk ,operational risk, liquidity risk, interest rate risk and $\mathcal{E}=$ error term.

The relationship between risk management and financial performance of financial institution, multiple regression analysis was used to determine this relationship. The SPSS program 16.0 version was used to analyze the data. Correlation and regression analysis were utilized to the role of risk management on financial performance of financial institution in Rwanda.

\section{Finds and Results}

\section{Analysis of the determinants of risk management}

Credit risk, liquidity risk, operational risk and interest rate risk are the determinant of risk management. Respondents indicate more than one source of information, it can be seen that Unguka bank Ltd most sources are analysis of financial statements as indicated by $33 \%$ of respondents. This implies that bank' sources are misleading in case of unclear or biased statements. However, $27 \%$ of respondents revealed the use of bank records, $17 \%$ confirmed the use of interview and inspection respectively. External sources of credit information represent $13 \%$ of responses, inspection of applicant's business has been revealed as used method on $7 \%$. While only $3 \%$ of respondents indicated the use of others means.

\section{Impact of risk management of credit portfolio quality of credit}

Management of credit risk expressed by the Unguka bank Ltd had a positive impact to the growth during the period 2011 to 2015 . The data show periodic satisfactory achievements (Table 1).

\section{Identification of indicators of performance}

Writings assert that bank's financial performance is measured by how better off the shareholder is at the end of a period, than he was at the beginning. The main objective of shareholders in investing in a business is to increase their wealth. Thus the measurements of performance of the Unguka bank Ltd are as follows:

Analysis of financial ratios: Financial ratios come to investing, analyzing financial statement information (also known as quantitative analysis), is one of, if not the most important element in the fundamental analysis process.

Return on assets ratio (ROA): Return on assets ratio is important profitability ratio because it measures the efficiency with which the company is managing its investment in asset and using them to generate profit. Return on assets ratio is also called the return on investment return on asset ratio during the covered period from 2013 up to 2015 , the ratio on return on assets are $3.0 \%, 3.6 \%$ and $3.9 \%$, respectively. This means from 2013 up to 2015. Unguka bank Ltd is profitable during the covered period because the standard ratio of return on asset is $1 \%$ may factors are the cause of that profitability but the quality service are the main cause of the increase of its profitability.

Return on equity ratio: Return on equity is a measure of how well a bank used reinvested earnings to generate additional earnings, equal to fiscal year' after tax. The ratio return on equity is most important of all financial ratios to investors in bank. It means return on money the investors have put into the bank. This is the ratio potential investors look at when deciding whether or not to invest in the bank. From 2013

\begin{tabular}{|c|c|c|c|c|c|}
\hline Indicator & 2011 & 2012 & 2013 & 2014 & 2015 \\
\hline \multicolumn{6}{|l|}{ Portofolio at risk } \\
\hline $1-30$ days & $0.0 \%$ & $0.0 \%$ & $2.4 \%$ & $4.2 \%$ & $0.3 \%$ \\
\hline $31-60$ days & $0.7 \%$ & $0.1 \%$ & $1.4 \%$ & $0.6 \%$ & $0.1 \%$ \\
\hline $61-90$ days & $0.0 \%$ & $0.0 \%$ & $0.0 \%$ & $0.0 \%$ & $0.3 \%$ \\
\hline $91-180$ days & $0.5 \%$ & $1.3 \%$ & $1.3 \%$ & $0.4 \%$ & $0.0 \%$ \\
\hline $181-365$ days & $1.0 \%$ & $0.7 \%$ & $0.3 \%$ & $1.6 \%$ & $1.9 \%$ \\
\hline > 365 days & $0.1 \%$ & $3.0 \%$ & $0.0 \%$ & $0.0 \%$ & $0.0 \%$ \\
\hline Re-phased (not currently in arrears) & $0.0 \%$ & $0.0 \%$ & $0.0 \%$ & $3.0 \%$ & $2.1 \%$ \\
\hline Total>1 day (PAR1) & $2.3 \%$ & $5.1 \%$ & $5.4 \%$ & $6.8 \%$ & $2.6 \%$ \\
\hline Total>30 days (PAR30) & $2.3 \%$ & $5.1 \%$ & $3.0 \%$ & $2.7 \%$ & $2.3 \%$ \\
\hline Total $>30$ days + rescheduling & $2.3 \%$ & $5.1 \%$ & $3.0 \%$ & $5.7 \%$ & $4.4 \%$ \\
\hline \multicolumn{6}{|l|}{ Protection } \\
\hline Ratio of reserves for loan losses & $1.3 \%$ & $4.5 \%$ & $2.0 \%$ & $2.0 \%$ & $2.0 \%$ \\
\hline Coverage of risk (PAR30 rescheduling + ) & $58 \%$ & $88 \%$ & $68 \%$ & $35 \%$ & $45 \%$ \\
\hline Ratio in provisions & & $5.9 \%$ & $2.9 \%$ & $2.6 \%$ & $2.3 \%$ \\
\hline \multicolumn{6}{|l|}{ Debt forgiveness } \\
\hline Rate of loan losses & & $0.0 \%$ & $2.4 \%$ & $1.6 \%$ & $1.6 \%$ \\
\hline$\%$ RAP into account past losses & $0.0 \%$ & $0.0 \%$ & $54.0 \%$ & $53.9 \%$ & $57.4 \%$ \\
\hline
\end{tabular}

Source: Summary of reports of the Unguka bank Ltd (2011- 2015).

Table 1: Portifolio quality. 
Citation: Harelimana JB (2017) The Role of Risk Management on Financial Performance of Banking Institutions in Rwanda. Bus Eco J 8: 284. doi: 10.4172/2151-6219.1000284

Page 4 of 5

up to 2015 , the ratio on return on equity are the following, $14.1 \%$ in $2013,18.6 \%$ in 2014 and $25.8 \%$ in 2015 , for 100 Rwf the investors has put into bank has brought $14.1 \%$ of the benefit in 2013 , for 100 Rwf the investors has put into bank has brought has got $18.6 \%$ in 2014, for 100 Rwf the investors has put into bank has brought $25.8 \%$ in 2015.

Net profit margin ratio: Profit margin, net margin, net profit margin or net profit ratio all refer to a measure of profitability. It is calculated by finding the net profit as a percentage of the revenue (Table 2).

The ratios above show the profitability of Unguka bank Ltd -Nyarugenge branch whereby in 2013 and 2014 one Franc of sales generated 0.08 and 0.14 Franc of net profit; 2015 one Franc of sales generated 0.16 Franc of net profit.

\section{The role of risk management for performance of Unguka bank Ltd}

In the literature, risk management seek economics for several reasons such as preventing credit risks, liquidity risks, operational risks and interest rate risks problems for the clients and staffs of Unguka bank Ltd in order to increase the level and quality of current asset, improve profitability. Thus, to further ascertain the role of risk management for Unguka bank Ltd performance in Nyarugenge branch, respondents were asked to indicate the role of risk management for Unguka bank Ltd performance (Table 3).

As asserted by different literatures, in every bank the overall aim is to make profit [7-10]. That is why Unguka bank were to improve profitability (43.3\%) improve firm efficiency (40.0\%), prevent default loans problems $(16.7 \%)$.

\section{Analysis of the relationship between risk management determinants and financial performance indicators}

The $F$-test was carried out to test the significance of the regression model in predicting the dependent variable ( performance of Unguka bank-Nyarugenge branch). From the results, it was found that the four independent variables (credit risk, interest rates risk, liquidity risk and operation risk predict the performance of Unguka bank-Nyarugenge branch (adjusted $R$ squared $=0.695$ ). That means the model explains $69.5 \%$ the variance in the performance of Unguka bank-Nyarugenge branch; $60.0 \%$ of variations are brought about by factors not captured in the objectives. Therefore, further research should be conducted to investigate the other factors $(60.0 \%)$ that affect performance of Unguka bank-Nyarugenge branch. The regression equation appears to be very useful for making predictions since the value of $R^{2}$ is close to 1 .

The findings shows hypotheses of the linear regression $F$-test results $(F=8.741$; and $5 \mathrm{df})$ are significant at $\mathrm{p}<0.05$. Therefore, the five

\begin{tabular}{|l|c|c|c|}
\hline Year & $\mathbf{2 0 1 3}$ & $\mathbf{2 0 1 4}$ & $\mathbf{2 0 1 5}$ \\
\hline Net profit"000"Rwf & 8.688 .765 & 11.781 .336 & 14.830 .235 \\
\hline Net sales in “000"Rwf & 98.524 .310 & 83.007 .293 & 92.630 .215 \\
\hline Ratio in \% & $8.8 \%$ & $14.2 \%$ & $16.0 \%$ \\
\hline
\end{tabular}

Table 2: Net profit margin ratio.

\begin{tabular}{|l|l|c|c|c|c|}
\hline Valid & $\begin{array}{l}\text { Prevent default loans } \\
\text { problems. }\end{array}$ & Frequency & Percent & $\begin{array}{c}\text { Valid } \\
\text { percent }\end{array}$ & $\begin{array}{c}\text { Cumulative } \\
\text { percent }\end{array}$ \\
\hline & 5 & 16.7 & 16.7 & .16 .7 \\
\hline Improve efficiency & 12 & 40.0 & 40.0 & 56.7 \\
\hline Improve profitability & 13 & 43.3 & 43.3 & 100.0 \\
\hline Total & 30 & 100.0 & 100.0 & \\
\hline
\end{tabular}

Source: Primary data.

Table 3: Role of risk management on performance of Unguka bank. hypotheses concluded that the regression model linearly explains the performance of Unguka bank-Nyarugenge branch. Therefore, the study accepted the alternative hypotheses:

- $\mathrm{H}_{\mathrm{a1}}$ : There is a relationship between credit risk and performance of Unguka bank-Nyarugenge branch;

- $\mathrm{H}_{\mathrm{a} 2}$ : There is a relationship between interest rates risk and performance of Unguka bank-Nyarugenge branch;

- $\mathrm{H}_{\mathrm{a} 3}$ : There is a relationship between liquidity risk and the performance of Unguka bank-Nyarugenge branch;

- $\mathrm{H}_{\mathrm{a} 4}$ : There is a relationship between operation risk and the performance of Unguka bank-Nyarugenge branch

- $\mathrm{H}_{\mathrm{a5}}$ There is a relationship between default loans and the performance of Unguka bank-Nyarugenge branch.

The study conducted a multiple regression analysis so as to determine the regression coefficients $(\beta)$ which shows that $\beta 0=1.138$ and which means that all the independent variables credit risk interest rates risk, liquidity risk, operational risk, and default loans have a significant contribution to Unguka bank-Nyarugenge branch performance even if the $\mathrm{x}$ variable equal to zero means $\mathrm{Y}=1.138$ and according to table 1 the model equation become $\mathrm{Y}=1.138+0.258 \mathrm{X}_{1}+0.367 \mathrm{X}_{2}+0.423 \mathrm{X}_{3}+0.15$ $7 \mathrm{X}_{4}+0.345 \mathrm{X}_{5}$

\section{Conclusions and Recommendations}

\section{Conclusions}

The general objective of this study is to assess the role of risk management on financial performance in banking institutions in Rwanda. The findings of the study was relevant due, use of risk management, are critical factors for financial performance as measured by ROA, ROE and Net income marginal. It concluded that the interactions use of risk management of the factors create an impetus for financial performance as measured by ROA, ROE and Net income marginal.

\section{Recommendations}

From the above analysis, it is recommended Unguka bank Ltd should emphasize more on training its personnel continuously particularly those in risk management in order to enable them apply accepted tools of risk management in a professional manner and to enable them give relevant and reliable answers to questions credit risk management. To help them in selecting correct investment projects of customers appropriately and in profession manner so as to avoid poor lending on numerous projects. The bank must train them in ways to promote non-payment services (customer care and public relations) to the public in order to attract good borrowers and maintain good customers.

\section{References}

1. Diacon SR and Carter RL (1984-1988) Success in Insurance (Second Edition), British library

2. Gallati R (2003) Risk management and capital adequacy. McGraw Hill Professional.

3. Sundharam KPM, Varshney PN (2002) Banking and Financial System. Sultan Chand and Sons, New Delhi.

4. Ross SA, Wester field KW, Jatte J (1996) Corporate Finance.

5. Dahir M (2013) Internal control and operational risk management. Mogadishu: Simad University. 
Citation: Harelimana JB (2017) The Role of Risk Management on Financial Performance of Banking Institutions in Rwanda. Bus Eco J 8: 284. doi: 10.4172/2151-6219.1000284

Page 5 of 5

6. Narwal KP, Jindal S (2015) The Impact of Corporate Goverance on the Profitability: An Empirical Study of Indian Textile Industry. Int J Res Manag, Sci Tech 3: 81-85.

7. Benston GJ (1983) Deposit Insurance and Bank Failure. Federal Research Bank of Atlanta, Economics Review 68: 4-17.
8. Adekunle SA, Maurice E (2014) The Impact of Corporate Governance on Performance of Quoted companies in Nigeria. Euro J Buss Mang 6: 9.

9. Oliver B (2000) Macro Economics, 2nd ed. Practice Hall New York.

10. Reuter P, Greenfield V (2001) Measuring global drug markets. World Economics 2: 159-173. 